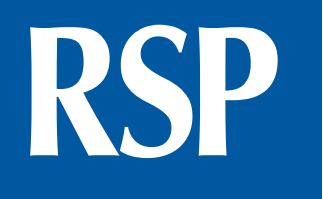

http://www.rsp.fsp.usp.br/
Revista de Saúde Pública

\title{
Were policies in Brazil effective to reducing trans fat from industrial origin in foods?
}

Flávia da Silva Lima Dias', Mário Ferreira Lima', Patricia Coelho de Velasco', Rosana Salles-Costa", Fátima Lúcia de Carvalho Sardinha', Maria das Graças Tavares do Carmo'

' Universidade Federal do Rio de Janeiro. Instituto de Nutrição Josué de Castro. Laboratório de Bioquímica Nutricional. Rio de Janeiro, RJ, Brasil

" Universidade Federal do Rio de Janeiro. Instituto de Nutrição Josué de Castro. Departamento de Nutrição Social e Aplicada. Rio de Janeiro, RJ, Brasil

\section{ABSTRACT}

OBJECTIVE: To determine the trans fatty acids content of processed foods frequently consumed by adults living in a Rio de Janeiro, Brazil, after the enactment of a mandatory trans fatty acids labelling policy.

METHODS: Between February 2014 and January 2015, a specifically dietary questionnaire was completed by 107 adults to assess the frequency of processed foods consumption. The most commonly consumed products from the survey, including vegetable oils, margarine, biscuits, snacks, cheese bread ( pão de queijo), french fries, cheeseburger and ice cream, were then analyzed for their trans fatty acids content using gas chromatography with a flame ionization detector.

RESULTS: Differences in the levels of trans fatty acids were observed among 22 products analyzed, considering that trans fatty acids content ranged between $0.0 \mathrm{~g} / 100 \mathrm{~g}$ in samples of cream cracker biscuit 1 and olive oil to $0.83 \mathrm{~g} / 100 \mathrm{~g}$ in samples of cheeseburger ( fast food), $0.51 \mathrm{~g} / 100 \mathrm{~g}$ in samples of frozen pão de queijo and $12.92 \mathrm{~g} / 100 \mathrm{~g}$ in samples of chocolate sandwich cookies with cream filling 2 . The overall trans fatty acids content of the different samples of margarine brands was $0.20 \mathrm{~g} / 100 \mathrm{~g}$ for brand 1 and $0.0 \mathrm{~g} / 100 \mathrm{~g}$ for brand 2 . These data are significantly lower than those observed in a survey conducted in 2003, when the regulation had been enacted.

Maria das Graças Tavares do Carmo Instituto de Nutrição Josué de Castro - UFRJ

Edificio do Centro de

Ciências da Saúde

Av. Carlos Chagas Filho, 373 Bloco J $2^{\circ}$ andar Sala 21 Illha do Fundão 21941-902 Rio de Janeiro, RJ, Brasil E-mail: tcarmo@nutricao.ufrj.br

Received: Sep 29, 2016

Approved: Jun 7, 2017

How to cite: Dias FSL, Lima MF, de Velasco PC, Salles-Costa R, Sardinha FLC, Tavares do Carmo MG. Were policies in Brazil effective to reducing trans fat from industrial origin in foods? Rev Saude Publica. 2018;52:34.

Copyright: This is an open-access article distributed under the terms of the Creative Commons Attribution License, which permits unrestricted use, distribution, and reproduction in any medium, provided that the original author and source are credited.
CONCLUSIONS: Our data indicate that Brazilian regulation is very likely implicated in the observed drop in trans fatty acids of the most processed foods but has yet to eliminate them, which reinforces the urgent need to revise the legislation, since a minimum amount of trans fat does not mean that the food product does not contain this type of fat.

DESCRIPTORS: Industrialized Foods. Trans Fatty Acids, analysis. Food Labeling, legislation \& jurisprudence. Legislation, Food. 


\section{INTRODUCTION}

Trans fatty acids (TFA) refer to a group of unsaturated fatty acids that contain one or more double bonds in a trans geometric configuration ${ }^{17}$. They are present in meat and dairy products as a by-product of fermentation in ruminant animals and in vegetable fats because of partial hydrogenation of the oils containing polyunsaturated fats ${ }^{11}$. The consumption of naturally occurring TFA originated from ruminants by human beings is generally low and it has been suggested - based on evidence - that it does not have adverse effects on health ${ }^{17,32}$. On the other hand, there is evidence that the consumption of industrially produced transfatty acids is associated with an increased risk of cardiovascular disease ${ }^{16,24,25}$, type 2 diabetes mellitus, Alzheimer's disease, cancer, as well as several other diseases ${ }^{11,14,24,25}$. A TFA intake of $5 \mathrm{~g}$ per day is associated with a $25 \%$ increase in the risk of ischemic heart disease ${ }^{30}$. As a consequence, the elimination from the food supply of partially hydrogenated vegetable oils containing TFA derived from industrial processes has been considered a very efficient action in the public health area in order to improve population diet and reduce the risk of chronic diseases ${ }^{9,22}$.

Hydrogenation of vegetable oils has been done commercially in Brazil since the late 1950s, as part of the industrial production process of shortening and hard margarine. This process led to a quick replacement of animal fats with processed vegetable fats in the diet of the Brazilian population. During this partial hydrogenation process, the temperature of polyunsaturated oils is increased in the presence of nickel or other catalyst metals and the material is exposed to hydrogen gas. Some of the double bonds are saturated in this process while others undergo geometric isomerism, changing to a trans configuration, or positional isomerism, being shifted to a different position in the aliphatic chain.

Over the last decades, the production of partially hydrogenated vegetable oils increased in Brazil. Because of their low cost, long shelf life, oxidative stability, semi-solidity at room temperature, and suitability for commercial frying ${ }^{17}$, these fats have been widely used in the production of several foods, such as margarine, chocolate spreads, biscuits, potato chips, and bakery products ${ }^{1}$. A study conducted in Brazil in 2003 showed that the average TFA content in fried potatoes from fast food restaurants was $4.74 \mathrm{~g} / 100 \mathrm{~g}$; in ice cream, the values varied from $0.041 \mathrm{~g} / 100 \mathrm{~g}$ to $1.41 \mathrm{~g} / 100 \mathrm{~g}$; and in cookies, the values varied from 2.81 $\mathrm{g} / 100 \mathrm{~g}$ to $5.60 \mathrm{~g} / 100 \mathrm{~g}^{5}$.

The food industry has increased efforts to reduce TFA amounts, especially in processed foods, due to the damaging health effects of TFA intake ${ }^{23}$. Most public health agencies have implemented labelling or ingredient restrictions on trans fats, including Brazil. In 2003, the National Sanitary Surveillance Agency (ANVISA) made obligatory the declaration of the TFA quantity on the nutritional labels of processed food commercialized in Brazil ${ }^{12}$. In addition, according to The Executive Board Resolution (Resolução da Diretoria Colegiada) no. 359 and no. 360, processed foods that contain an amount of trans fat less than or equal to 0.2 $\mathrm{g} /$ portion can be considered as "does not contain trans fat" and was also described as "not significant" in the Resolution ${ }^{21}$. Moreover, when the quantity of trans fat does not reach the minimum limit recommended by the legislation ( $0.2 \mathrm{~g} /$ portion), the food industry is under no obligation to display the content on the label, thus impairing any nutritional analysis on food regarding trans fat $^{28}$.

It is necessary to keep active the process of trans fat content assessment in food labels available in Brazil in order to estimate intakes and to support the choice of public policies related to risk management. This study aims to provide updated information on the levels of TFA found in processed foods with high level of consumption in Rio de Janeiro, Brazil, after the TFA labelling became mandatory by legislation. To assess the changes in trans fat levels in Brazilian industrialized foods over the past decade, the data are compared with surveys done in 2003, which evaluated manufactured foods ${ }^{5}$. 


\section{METHODS}

\section{Study Design and Participants}

The survey carried out in 2014-2015 included 107 adults, 20 to 50 year old male and female living in Duque de Caxias, state of Rio de Janeiro, Brazil. Duque de Caxias city was chosen for the study because it is an important industrial center with a population of about 842,686, located in the metropolitan area of Rio de Janeiro and within a distance of no more than 30 $\mathrm{km}$ from Rio de Janeiro city ${ }^{6}$. Considering it is an exploratory study, the sample was formed by convenience. Participants were recruited from a basic public health unit. The Human Ethics Committee of the Universidade Federal do Rio de Janeiro approved the study and all participants gave informed consent. Participants were excluded if they were affected by a metabolic disorder or were taking medication known to alter plasma lipids.

The self-administered questionnaire on the frequency of processed foods consumption was applied. The questionnaire inquired only about the frequency of consumption without specifying portion size. Participants were asked how often, on average, they had consumed these foods over the past six mo. Six predefined frequency categories ranging from "never/ seldom" to "four or more times per week" were used. Also, open questions were conducted about daily consumption of five different types of margarine and oil. Foods with a frequency of consumption reported to be equal to or higher than two to four times a week were considered the most commonly consumed ones. Twenty-two products were selected for analysis (Box).

\section{Sampling}

The analysis was performed on samples of food purchased by the participants in supermarkets or other usual points of sale listed. All samples were stored following the recommendations found on their labels and the ready-to-eat takeaway products were stored in the refrigerator and frozen as quickly as possible. If certain sub-samples required any kind of preparation or cooking, they were processed strictly following the manufacturers' instructions, by usual domestic practices.

For each product, five samples from three different batches were purchased. To allow for thorough homogenization of samples and to obtain representative aliquots ${ }^{26}$ of the products analyzed, five samples from the same batch were homogenized to obtain a composite sample.

Box. Products selected for analysis of trans fatty acids.

\begin{tabular}{|c|c|}
\hline Food category & Selected food \\
\hline Oils and fats & $\begin{array}{c}\text { Soybean oil brand } 1 \\
\text { Soybean oil brand } 2 \\
\text { Olive oil } \\
\text { Margarine brand } 1 \\
\text { Margarine brand } 2\end{array}$ \\
\hline Cream crackers ${ }^{\mathrm{a}}$ and cookies & $\begin{array}{c}\text { Cream crackers brand 1 } \\
\text { Cream crackers brand } 2 \\
\text { Cookies without filling } \\
\text { Chocolate sandwich cookies with chocolate-flavored filling brand } 1 \\
\text { Chocolate sandwich cookies with chocolate-flavored filling brand } 2 \\
\text { Plain sandwich cookies with chocolate-flavored filling }\end{array}$ \\
\hline Snacks & $\begin{array}{l}\text { Ham-flavored } \\
\text { Barbecue-flavored } \\
\text { Cheese-flavored brand } 1 \\
\text { Cheese-flavored brand } 2 \\
\text { Shoestring potatoes brand } 1 \\
\text { Shoestring potatoes brand } 2\end{array}$ \\
\hline Fast foods & $\begin{array}{l}\text { Cheeseburger } \\
\text { French fries }\end{array}$ \\
\hline Frozen food & $\begin{array}{l}\text { Pão de queijo } \\
\text { Ice cream brand } 1 \text { - chocolate, vanilla, and strawberry flavors } \\
\text { Ice cream brand } 2 \text { - chocolate, vanilla, and strawberry flavors }\end{array}$ \\
\hline
\end{tabular}

${ }^{a}$ Crackers made from water, flour, and fat.

${ }^{\mathrm{b}}$ A savory bun made from sour manioc starch, eggs, milk, oil, and cheese. 
The same was done for the other two batches purchased. Three composite samples (each with 15 sub-samples) were formed and prepared for TFA analysis. A total of 42 samples were analyzed.

\section{Sample Preparation}

Sub-samples were homogenized and combined into composite samples for analysis on an equal weight basis and were stored frozen at $-40^{\circ} \mathrm{C}$ until required for analysis.

The homogenization of the samples was performed at room temperature. Solid samples were homogenized in $0.9 \%$ saline solution using a mini processor, while liquid and creamy samples, such as oils and margarine, were shaken in glass tubes without processor usage.

\section{Sample Analysis}

Lipid extraction and preparation of fatty acid methyl esters (FAME)

The extraction of lipids, saponification, and methylation of fatty acids contained in the samples were performed using the method of the Association of Official Agricultural Chemists Ce $1 \mathrm{j}-07^{2}$ and with FAME derivatization procedure using BF3 14\% in methanol according to International Standards - ISO 5509 (2000). The FAME in the fat samples were collected in vials proper for gas chromatograph (GC) autosampler and stored at $-20^{\circ} \mathrm{C}$ for subsequent analysis of fatty acids.

\section{Gas Chromatograph Analysis of Fatty Acid Methyl Esters}

The FAME were identified by the Agilent model 7890 GC instrument (Palo Alto, CA, USA) equipped with a flame ionization detector and the EZ Chrom Elite software and using the modified temperature program ${ }^{8,19}$. A highly polar fused silica capillary column $\mathrm{SP}^{\mathrm{TM}}-2560$ $0.25 \mathrm{~mm}$ i.d. $\times 100 \mathrm{~m}$ length, coated with $100 \%$ cyanopropyl polysiloxane stationary phase, film thickness $0.20 \mu \mathrm{m}$, were used (Supelco, Inc., Bellefonte, PA, USA) to separate the FAME. The temperature of injector and detector were maintained at $250.0^{\circ} \mathrm{C}$, with a split ratio of 1:100, $1 \mu \mathrm{L}$ of standard or sample, equivalent to $20 \mu \mathrm{g}$ of total FAME were injected using an autosampler device in each GLC run. The oven temperature program developed was: initial temperature $100.0^{\circ} \mathrm{C}$ ramped $3.0^{\circ} \mathrm{C} / \mathrm{min}-140.0^{\circ} \mathrm{C}$, ramped $0.5^{\circ} \mathrm{C} / \mathrm{min}-170^{\circ} \mathrm{C}$, ramped $4.0^{\circ} \mathrm{C} /$ min $-220.0^{\circ} \mathrm{C}$, maintained for 35 minutes. Carrier gas hydrogen, make up gas nitrogen, and hydrogen and air for the flame ionization detector were used. Each determination was run at least in triplicate. The individual FAME was achieved by comparison of its relative retention time to those of commercial standards (GLC-463- Nu-Chek Prep. Inc) and other referenced FAME standards. Quantification of the fatty acids was carried out by calculating the response factors of individual fatty acid isomers. Total TFA was calculated as the sum of t7-C18:1(trans-7-octadecenoic acid), t9-C18:1(trans elaidic acid), t11-C18:1(trans vaccenic acid), t12-C18:1(trans-12-octadecenoic acid) and t9, t12-C18:2 (trans linolelaidic acid).

\section{Statistical Analysis}

The results are expressed as mean value and standard deviation. The results were compared using analysis of variance with a $5 \%$ significance leve ${ }^{29}$. For all table analysis and preparation we used Microsoft $\AA$ Office Excel (version 10.0).

\section{RESULTS AND DISCUSSION}

The main findings of this cross-sectional study show that there was a drop in TFA content of processed foods frequently consumed in Rio de Janeiro, Brazil, that coincided with labelling regulation employed in 2003 by the ANVISA. Although significant progress has been made with labelling regulation in Brazil, TFA levels need to be reduced even more, particularly in fast foods and some types of biscuits. 
The TFA comprised isomers of 16:1, 18:1 and 18:2 acids and trans 18:1 isomers were the major group of TFA present in most brands analyzed, ranging from 0.0 to $12.38 \mathrm{~g} / 100 \mathrm{~g}$ of product (Table).Highest TFA concentrations were observed in brand 2 cream-filled chocolate sandwich cookies while no TFA were present in olive oil and brand 1 cream cracker biscuit. Unlike our results, a previous study ${ }^{18}$ that also evaluated cream cracker biscuits in Brazil revealed TFA levels ranging from $12.2 \%$ to $31.2 \%$ of total fatty acids and the mean value was $20.1 \%$. However, that study was conducted before the change in Brazilian legislation ${ }^{12}$ that demanded TFA labeling on all packaged foods. Dias and Gonçalves ${ }^{7}$ assessed the nutritional labeling of 150 samples of different brands of biscuits, chocolates, and ice cream. Those authors found that about $55 \%$ of the products analyzed were not adequate to the ANVISA's legislation, particularly regarding the portion size information and the TFA content. In another study, the TFA level in some margarines purchased at supermarkets in Brazil remained over $50 \%$ after regulation ${ }^{3}$. Finally, when comparing the TFA concentrations found in this study with those found by Winter et al. ${ }^{33}$, there is a high reduction of this type of fatty acid in straw potatoes - also known as shoestring fries potatoes - sold in Brazil (almost $15 \mathrm{~g} / 100 \mathrm{~g}$ ), probably by replacing the hydrogenated vegetable fat used for frying with other types of oils. Therefore, the removal of partially hydrogenated vegetable fat, containing industrially produced TFA, in processed food by Brazilian industries was not an easy and fast procedure when compared to other countries.

Recently we demonstrated low levels of TFA in biscuits frequently consumed by Brazilian college students in the period of 2009-2011 ${ }^{8}$. In addition, high levels of palmitic acid were found, indicating the likely use of palm oil in manufacturing. Likewise, in the current study, palm oil appears to be the main hydrogenated vegetable fat substitute in the manufacture of processed foods, since high levels of saturated fatty acids, particularly palmitic acid, were found in the samples. Exceptions were brand 2 margarine and barbecue-flavored salty biscuit, in which soybean oil was possibly used due to the higher content of polyunsaturated fatty

Table. Trans fatty acid (TFA) content (g/100 g) (presented by mean and SD) of the analyzed samples.

\begin{tabular}{|c|c|c|c|c|c|c|c|c|}
\hline Product & C16:0 & C18:2 n6 & $\mathrm{C} 16: 1 \mathrm{t}^{\mathrm{a}}$ & $\mathrm{C} 18: 1 \mathrm{t}^{\mathrm{b}}$ & $\mathrm{C} 18: 2 \mathrm{t}^{\mathrm{c}}$ & $\begin{array}{l}\text { Total } \\
\text { SFA }\end{array}$ & $\begin{array}{l}\text { Total } \\
\text { TFA }\end{array}$ & $\begin{array}{l}\text { TFA per } \\
\text { serving }\end{array}$ \\
\hline Soybean oil brand 1 & $10.97(3.33)$ & $48.26(5.36)$ & 0.00 & 0.00 & $0.09(0.01)$ & 14.74 & 0.09 & 0.01 \\
\hline Soybean oil brand 2 & $10.02(0.62)$ & $47.56(3.67)$ & 0.00 & 0.00 & $0.26(0.01)$ & 13.44 & 0.26 & 0.03 \\
\hline Olive oil & $9.30(0.55)$ & $4.90(0.93)$ & 0.00 & 0.00 & 0.00 & 12.62 & 0.00 & 0.00 \\
\hline Margarine brand 1 & $10.99(1.22)$ & $39.08(3.95)$ & $0.03(0.10)$ & $0.21(0.10)$ & $0.65(0.01)$ & 16.87 & 0.86 & 0.09 \\
\hline Margarine brand 2 & $3.76(1.28)$ & $15.91(7.88)$ & 0.00 & 0.00 & $0.20(0.07)$ & 8.18 & 0.20 & 0.03 \\
\hline Cream crackers brand 1 & $7.11(0.74)$ & $2.61(0.25)$ & 0.00 & 0.00 & 0.00 & 8.35 & 0.00 & 0.00 \\
\hline Cream crackers brand 2 & $11.11(1.89)$ & $4.13(0.80)$ & 0.00 & $0.04(0.01)$ & $0.08(0.02)$ & 12.95 & 0.12 & 0.04 \\
\hline Cookies & $6.94(0.52)$ & $2.61(0.23)$ & 0.00 & 0.00 & $0.01(0.00)$ & 8.28 & 0.01 & 0.00 \\
\hline $\begin{array}{l}\text { Chocolate sandwich cookie with } \\
\text { chocolate-flavored filling brand } 1\end{array}$ & $8.27(0.91)$ & $7.29(0.80)$ & 0.00 & $0.47(0.11)$ & $0.05(0.01)$ & 11.44 & 0.52 & 0.16 \\
\hline $\begin{array}{l}\text { Chocolate sandwich cookie with } \\
\text { chocolate-flavored filling brand } 2\end{array}$ & $2.47(0.12)$ & $1.52(0.12)$ & 0.00 & $12.38(1.16)$ & $0.54(0.02)$ & 4.71 & 12.92 & 3.88 \\
\hline $\begin{array}{l}\text { Plain sandwich cookie with chocolate- } \\
\text { flavored filling }\end{array}$ & $4.41(0.10)$ & $6.69(0.39)$ & 0.00 & $0.06(0.00)$ & $0.13(0.00)$ & 6.97 & 0.19 & 0.00 \\
\hline Ham-flavored savory biscuit & $11.00(0.98)$ & $3.74(0.35)$ & 0.00 & 0.00 & $0.06(0.00)$ & 12.78 & 0.06 & 0.02 \\
\hline Barbecue-flavored savory biscuit & $3.02(0.20)$ & $14.35(0.88)$ & 0.00 & 0.00 & $0.05(0.02)$ & 4.46 & 0.05 & 0.01 \\
\hline Cheese-flavored savory biscuit brand 1 & $1.91(0.17)$ & $1.70(0.53)$ & $0.01(0.00)$ & $0.05(0.01)$ & $0.02(0.00)$ & 2.66 & 0.07 & 0.00 \\
\hline Cheese-flavored savory biscuit brand 2 & $5.97(0.04)$ & $1.88(0.02)$ & $0.01(0.00)$ & 0.00 & $0.04(0.00)$ & 7.12 & 0.05 & 0.00 \\
\hline Shoestring potatoes brand 1 & $15.00(0.21)$ & $4.32(0.03)$ & $0.02(0.00)$ & $0.08(0.00)$ & $0.11(0.01)$ & 17.81 & 0.21 & 0.05 \\
\hline Shoestring potatoes brand 2 & $6.63(0.26)$ & $15.42(0.77)$ & $0.01(0.00)$ & $0.05(0.00)$ & $0.21(0.01)$ & 7.89 & 0.27 & 0.05 \\
\hline Cheeseburger (fast food) & $4.36(0.16)$ & $1.20(0.09)$ & 0.00 & $0.75(0.04)$ & $0.08(0.02)$ & 9.49 & 0.83 & $-d$ \\
\hline French fries (fast food) & $2.04(0.24)$ & $7.31(0.69)$ & 0.00 & 0.00 & $0.01(0.00)$ & 2.84 & 0.07 & $-d$ \\
\hline Frozen pão de queijo & $3.71(0.42)$ & $4.97(0.44)$ & $0.03(0.01)$ & $0.43(0.01)$ & $0.04(0.01)$ & 7.30 & 0.51 & 0.23 \\
\hline Ice cream 1 & $3.18(0.03)$ & $0.71(0.05)$ & 0.00 & $0.01(0.00)$ & $0.03(0.00)$ & 3.91 & 0.04 & 0.02 \\
\hline Ice cream 2 & $2.99(0.14)$ & $0.74(0.03)$ & 0.00 & 0.00 & $0.02(0.00)$ & 3.92 & 0.02 & 0.01 \\
\hline
\end{tabular}

$\mathrm{t}$ : trans; c: cis

${ }^{\text {a } C 16: 1 ~ 9 t, ~ C 16: 1 ~ 11 t ~}$

${ }^{\text {b } C 18: 16 t+8 t, C 18: 19 t, C 18: 110 t, C 18: 1 ~ 11 t, ~ C 18: 1 ~ 13 t+14 t ~}$

${ }^{c}$ C18:2 9t.12t, C18:2 9t.12c, C18:2 11t.15c, C18:2 7t. 9t

d Portion not established. 
acids, particularly linoleic acid (Table). These results highlight another concern: the use of alternative fats to decrease TFA contents produces industrialized food products with high levels of saturated fatty acids or low content of essential fatty acids. Additionally, it has been reported that a high intake of palm oil contributes to the development of coronary heart disease $\mathrm{e}^{10,15,31}$. Then, countries whose crops originate oils rich in mono- or polyunsaturated fatty acids ${ }^{27}$ may find it easier to change from partially hydrogenated vegetable oils to those with fewer adverse effects on health. In Argentina, for instance, the shift to high-oleic sunflower oil in order to reformulate food production was far easier than similar modifications that occurred in Brazil, where a significant increase in the palm oil production has taken place over the last decades ${ }^{20}$.

The use of palm oil as the main substitute for hydrogenated vegetable fat was also observed by Gagliardi et al. ${ }^{13}$ in foods sold in Brazil, such as margarines, cookies and fast food products. As ascertained in the present study, there was an increase in palmitic acid levels associated with the reduction of TFA in these foods.

There are alternatives to TFA that can be used in product reformulation, including interesterification. The process allows the production of trans fat free or very low content of TFA, from the rearrangement of fatty acids in ester bonds of glycerol and consequent change in melting point and crystallization of fat. As the result, this process influences the physical characteristics of fats. Interesterified fats for commercial use are usually generated from the random interesterification of a liquid oil ( for example soy oil) with a fully hydrogenated fat or blends of palm-stearin fractions $s^{4}$. The final product presents the functionality desired by the food industry, with an increased proportion of solid fat content without TFA. This process could be the responsible for the low TFA content in brand 1 margarine.

According to Brazilian legislation, a product can be classified as TFA-free when it contains, per portion, less than $0.2 \mathrm{~g}^{21}$. In the present study, only frozen cheese bread and brand $2 \mathrm{cream}$ filled chocolate sandwich cookies can be considered, according to Brazilian legislation, a source of TFA products, with $0.23 \mathrm{~g}$ and $3.76 \mathrm{~g}$ per serving of the product. However, attention should be paid to the question of the amount consumed since often ingestion is greater than single portion, resulting in an intake of considerable amounts of TFA. Thus, those who consume higher quantities may represent a significant intake of trans fats. On the other hand, stricter regulation has been considered in recent years in the United States by the Food and Drug Administration (FDA 2013), where steps have been taken to no longer define partially hydrogenated oils - the primary source of industrially produced TFA - as generally recognized as safe. In 2015, the FDA has made its final determination that there is no longer a consensus among qualified experts that partially hydrogenated oils are generally recognized as safe for any use in human food. Thus, following the global trend towards the elimination of trans fat consumption, it would be important to revise the official Brazilian documents on trans fat.

In the present study, when different brands of the same product are compared, it is observed that the food industry may use different lipid sources to manufacture similar items. For example, some biscuits were made with partially hydrogenated fat, while others were made with olive oil. Consequently, this could affect not only the lipid quality of the final product but also the price to the consumer - in market research, it was found that, overall, the products that had higher trans fatty acid levels are the cheaper ones. These differences were detected in oils and margarines, but mostly in sweet biscuits with filling. It is important to notice that the brand 2 of this biscuit, which showed high levels of TFA, was a product cheaper than the similar one. Additionally, the lipid composition indicates the use of hydrogenated vegetable fat as an ingredient in its industrial process. In fact, the official Brazilian legislation recommends that consumers consult the list of product ingredients because indications of the absence of trans fat in the nutritional information cannot be considered safe. However, Silveira ${ }^{29}$ detected different forms of fat source of TFA representation on food labels as "partially hydrogenated oils", "hydrogenated vegetable fat", "hydrogenated vegetable oil", among others. In addition, terms may be found as "fat", "vegetable cream", and "margarine", which do not inform whether or not it has TFA. For the products analyzed, we found terms such 


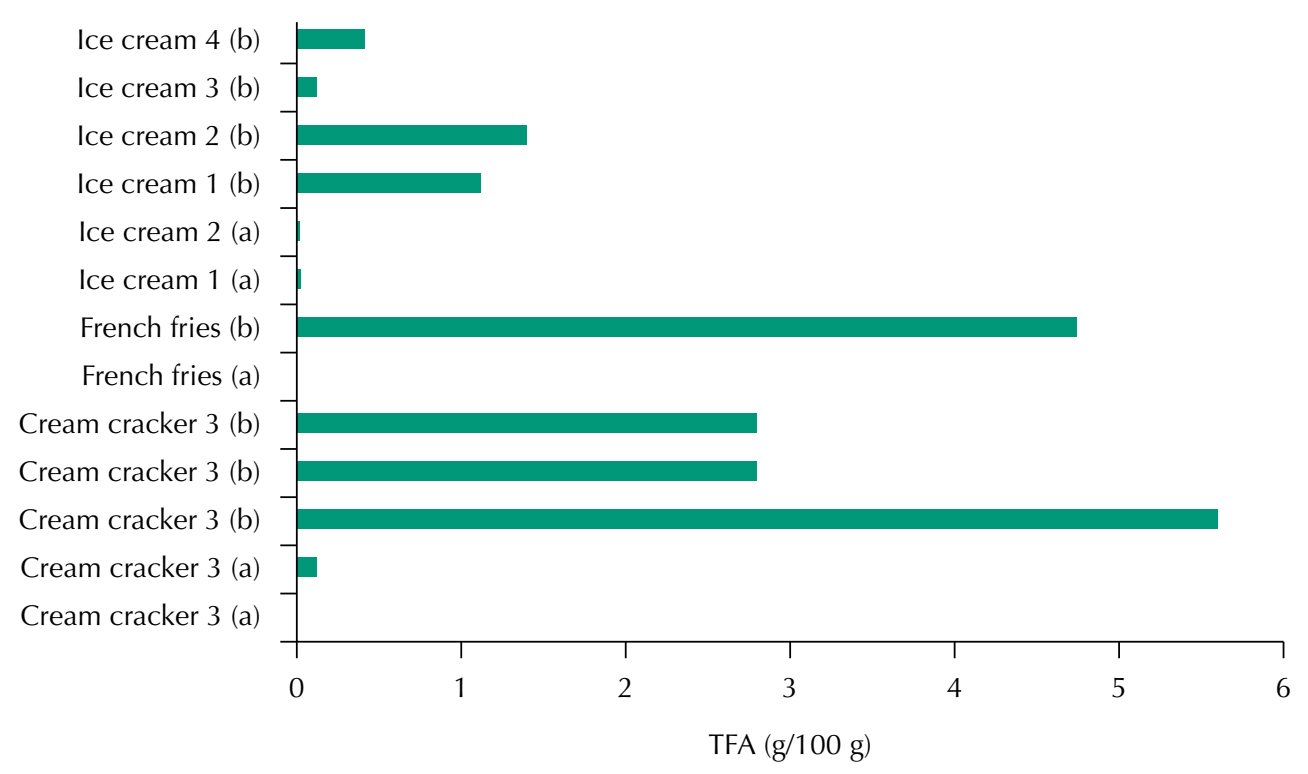

TFA: trans fatty acids

Figure. Comparison of trans fatty acid content (g/100 g) of cream crackers, french fries, and cheese bread in the present study (a) and values reported in the literature (5) before the introduction of Brazilian legislation on the subject (b).

as "vegetable fat", "hydrogenated vegetable fat", "margarine", "soybean oil", "interesterified vegetable fat", and "vegetable oil interesterified". This lack of standardization may confuse consumers as to the quality of fat added to the product.

It is probable that TFA food content in Brazil is declining due to the food industry's progress in reducing the trans fat content in a wide range of products and due to more awareness of food choices by the consumers. Researchers analyzed products in the city of Rio de Janeiro in 2003, prior to legislation aimed at reducing the use of hydrogenated fats by the food industry, and they found high levels of TFA ${ }^{5}$. On the other hand, data from the current study indicate low levels of these fatty acids in similar products, as shown in Figure 1.

\section{CONCLUSIONS}

TFA content varied between $0.00 \mathrm{~g}$ and $0.86 \mathrm{~g} / 100 \mathrm{~g}$ with exception of one sample (12.92 $\mathrm{g} / 100 \mathrm{~g}$ ) and different values were found among similar products, indicating distinct lipid sources in food production.

The results found in this study and their comparison with studies conducted prior to the Brazilian legislation indicate that replacing TFA-rich fats with alternative sources has been done by the food industry, although it has not been observed in all analyzed products. However, there is little information about the quality of fats used in this replacement that could potentially result in increased consumption of saturated fats.

\section{REFERENCES}

1. Ansorena D, Echarte A, Ollé R, Astiasarán I. 2012: no trans fatty acids in Spain bakery products. Food Chem. 2013;138(1):422-9. https://doi.org/10.1016/j.foodchem.2012.10.096

2. Association of Official Analytical Chemists. AOCS Official Method Ce 1j-07: determination of cis-, trans-, saturated, monounsaturated, and polyunsaturated fatty acids in extracted fats by capillary GLC. Urbana: AOCS; 2007.

3. Benincá C, Zanoelo EF, Luz Jr LFL, Spricigo CB. Trans fatty acids in margarines marketed in Brazil: content, labelling regulations and consumer information. Eur J Lipid Sci Technol. 2009;111(5):451-8. https://doi.org/10.1002/ejlt.200800185 
4. Cavendish TA, Lemos PB, Yokota RT, Vasconcelos TF, Coêlho PF, Buzzi M, et al. [Fatty acid composition of hydrogenated or interesterified margarines]. Cienc Tecnol Aliment. 2010;30(1):138-42. Portuguese. https://doi.org/10.1590/S0101-20612010005000018

5. Chiara VL, Sichieri R, Carvalho TSF. [Trans fatty acids of some foods consumed in Rio de Janeiro, Brazil]. Rev Nutr. 2003;16(2):227-33. Portuguese. https://doi.org/10.1590/S1415-52732003000200010

6. Costa Neto C. Vila Rosário: o resgate de uma sociedade pela ciência, pela tecnologia, pelo trabalho e pela compreensão. Rio de Janeiro: Cálamo Produção Editorial; 2002.

7. Dias JR, Gonçalves ECBA. [Consumption and analysis of nutricional label of foods with high content of trans fatty acids]. Cienc Tecnol Aliment. 2009;29(1):177-82. Portuguese. https://doi.org/10.1590/S0101-20612009000100027

8. Dias FSL, Passos MEA, Carmo MGT, Lopes MLM, Mesquita VLV. Fatty acid profile of biscuits and salty snacks consumed by Brazilian college students. Food Chem. 2015;171:351-5. https://doi.org/10.1016/j.foodchem.2014.08.133

9. Downs SM, Thow AM, Leeder SR. The effectiveness of policies for reducing dietary trans fat: a systematic review of the evidence. Bull World Health Organ. 2013;91(4):262-9H. https://doi.org/10.2471/BLT.12.111468

10. Fattore E, Bosetti C, Brighenti F, Agostoni C, Fattore G. Palm oil and blood lipid-related markers of cardiovascular disease: a systematic review and meta-analysis of dietary intervention trials. Am J Clin Nutr. 2014;99(6):1331-50. https://doi.org/10.3945/ajcn.113.08119

11. Filip S, Fink R, Hribar J, Vidrih R. Trans fatty acid in food and their influence on human health. Food Technol Biotechnol. 2010 [cited 2017 Nov 29];48(2):135-42. Available from: http://www.ftb.com.hr/images/pdfarticles/2010/April-June/48_135.pdf

12. Food and Drug Administration (US). FDA to extend comment period of measure to further reduce trans fat in processed food. 2013. Available from: https://www.federalregister. gov/documents/2013/12/31/2013-31294/tentative-determination-regarding-partiallyhydrogenatedoils-request-for-comments-and-for

13. Gagliardi ACM, Mancini Filho J, Santos RD. [Nutritional profile of foods with zero trans fatty acids claim]. Rev Assoc Med Bras. 2009;55(1):50-3. Portuguese. https://doi.org/10.1590/S0104-42302009000100015

14. Garbarino J, Sturley SL. Saturated with fat: new perspectives on lipotoxicity. Curr Opin Clin Nutrit Metab Care. 2009;12(2):110-6. https://doi.org/10.1097/MCO.0b013e32832182ee

15. Hoenselaar R. Saturated fat and cardiovascular disease: the discrepancy between scientific literature and dietary advice. Nutrition. 2012;28(2):118-23. https://doi.org/10.1016/j.nut.2011.08.017

16. Hu FB, Manson JE, Willett WC. Types of a dietary fat and risk of coronary hearth disease: a critical review. J Am Coll Nutr. 2001;20(1):5-19. https://doi.org/10.1080/07315724.2001.10719008

17. Lottenberg AMP. [Importance of the dietary fat on the prevention and control of metabolic disturbances and cardiovascular disease]. Arq Bras Endocrinol Metab. 2009;53(5):595-607. Portuguese. https://doi.org/10.1590/S0004-27302009000500012

18. Martin CA, Carapelli R, Visantainer JV, Matsushita M, Souza NE. Trans fatty acids in Brazilian biscuits. Food Chem. 2005;93(3):445-8. https://doi.org/10.1016/j.foodchem.2004.10.022

19. Masson L, Alfaro T, Camilo C, Carvalho A, Illesca P, Torres R, et al. Fatty acid composition of soybean/ sunflower mix oil, fish oil and butterfat applying the AOCS Ce $1 \mathrm{j}-07$ method with a modified temperature program. Grasas Aceites. 2015;66(1):e064. https://doi.org/10.3989/gya.0692141

20. Ministério da Agricultura, Pecuária e Abastecimento (BR). Instrumentos indutores do Programa de Produção Sustentável de Óleo de Palma no Brasil. Brasília (DF); 2010 [cited 2017 Nov 29]. Available from: http://www.agricultura.gov.br/pls/url/ITEM/85D6620F0A777CDBE040A8C0750 22DA2.

21. Ministério da Saúde (BR), Agência Nacional de Vigilância Sanitária. Resolução RDC $n^{\circ} 360$, de 23 de dezembro de 2003. Brasília (DF); 2003 [cited 2017 Nov 29]. Available from: http://portal. anvisa.gov.br/documents/33880/2568070/res0360_23_12_2003.pdf/5d4fc713-9c66-4512-b3c1afee $57 \mathrm{e} 7 \mathrm{~d} 9 \mathrm{bc}$

22. Mozaffarian D, Stampfer MJ. Removing industrial trans fat from foods. BMJ. 2010;340:c1826. https://doi.org/10.1136/bmj.c1826

23. Norris S. Trans fats: the health burden. Ottawa: Library of Parliament, Science Technoogy Division; 2005 [cited 2017 Nov 29]. p1-16. Available from: https://lop.parl.ca/content/lop/ ResearchPublications/prb0521-e.pdf 
24. Oh K, Hu FB, Manson JE, Stampfer MJ, Willet WC. Diteray fat intake and risk of coronary hearth disease in women: 20 years of follow-up of nurses' health study. Am J Epidemiol. 2005;161(7):672-9. https://doi.org/10.1093/aje/kwi085

25. Oomen CM, Ocké MC, Feskens EJM, Erp Baart MAJ, Kok FJ, Kromhout D. Association between trans fatty acid intake and 10 year risk of coronary hearth disease in the Zutphen Elderly Study: prospective population based study. Lancet. 2011;357(9258):746-51. https://doi.org/10.1016/S0140-6736(00)04166-0

26. Organisation Internationale de Métrologie Légale. Recommendation 87 (OIML R87) on the "Quantity of products in prepackages". Paris: OIML; 2004.

27. Pan American Health Organization. Healthy oils and the elimination of industrially produced trans fatty acids in the Americas: initiative for the prevention and control of chronic diseases. Washington (DC): PAHO; 2008 [cited 2017 Nov 29]. Available from: http://www. healthycaribbean.org/nutrition_and_diet/documents/TransFats.pdf.

28. Proença RPC, Silveira BM. Intake recommendations and labeling of trans fat in processed foods in Brazil: analysis of official documents. Rev Saude Publica. 2012;46(5):923-8. https://doi.org/10.1590/S0034-89102012000500020

29. Silveira BM. [Food and nutrition information of trans fat on labels of processed food products [dissertation]]. Florianópolis: Universidade Federal de Santa Catarina; 2011 [cited 2017 nov 29]. Portuguese. Available from: https://repositorio.ufsc.br/xmlui/bitstream/ handle/123456789/95753/288948.pdf?sequence $=1$

30. Stender S, Dyerberg J, Bysted A, Leth T, Astrup A. A trans world journey. Atheroscler Suppl. 2006;7(2):47-52. httsp://doi.org/10.1016/j.atherosclerosissup.2006.04.011

31. Sun Y, Neelakantan N, Wu Y, Lote-Oke R, Pan A, Dam RM. Palm oil consumption increases LDL cholesterol compared with vegetable oils low in saturated fat in a meta-analysis of clinical trials. J Nutr. 2015;145(7):1549-58. https://doi.org/10.3945/jn.115.210575

32. Wang $Y$, Jacome-Sosa MM, Proctor SD. The role of ruminant trans fat as a potential nutraceutical in the prevention of cardiovascular disease. Food Res Int. 2012;46(2):460-8. https://doi.org/10.1016/j.foodres.2011.08.019

33. Winter CMG, Yamamoto Cl, Baggio SR, Moreira JT, Freitas RJS. Determinação de ácidos graxos trans em batata palha comercializada na cidade de Curitiba, PR. Bol Centro Pesq Process Aliment. 2006;24(2):475-89. https://doi.org/10.5380/cep.v24i2.7502

Funding: Fundação Carlos Chagas Filho de Amparo à Pesquisa do Estado do Rio de Janeiro (FAPERJ - Process E-26/101.561/2010), Conselho Nacional de Desenvolvimento Científico e Tecnológico (CNPq - Process 308172/2012-4), and the Coordenação de Aperfeiçoamento de Pessoal de Nível Superior (CAPES - Process 23038.002686/2014-55).

Authors' Contribution: Design and planning of the study: FLCS, MGTC, RSC. Collection, analysis, and interpretation of the data: FSLD, MFL, RSC, FLCS, MGTC. Preparation or review of the study: FSLD, PCV, MGTC. Approval of the final version: FSLD, MFL, PCV, RSC, FLCS, MGTC. Public responsibility for the content of the article: MGTC.

Conflict of Interest: The authors declare no conflict of interest. 